University of Chicago Law School

Chicago Unbound

Journal Articles

Faculty Scholarship

1970

\title{
The Consumption and Loss of Personal Property under the Internal Revenue Code
}

Richard A. Epstein

Follow this and additional works at: https://chicagounbound.uchicago.edu/journal_articles

Part of the Law Commons

\section{Recommended Citation}

Richard A. Epstein, "The Consumption and Loss of Personal Property under the Internal Revenue Code," 23 Stanford Law Review 454 (1970).

This Article is brought to you for free and open access by the Faculty Scholarship at Chicago Unbound. It has been accepted for inclusion in Journal Articles by an authorized administrator of Chicago Unbound. For more information, please contact unbound@law.uchicago.edu. 


\title{
The Consumption and Loss of Personal Property Under the Internal Revenue Code
}

\author{
Richard A. Epstein *
}

This Article examines the effects that the consumption and loss of personal property ${ }^{1}$ should have upon the determination of taxable income. The provisions of the Internal Revenue Code material to this inquiry are few in number and simple in form. The Code's general rule states that personal, living, and family expenses are not deductible from gross income, ${ }^{2}$ whereas deductions may be taken for the ordinary and necessary expenses paid or incurred in the production or collection of income or in the maintenance of income-producing property. ${ }^{3}$ One exception to the rule that personal expenses are not deductible will be studied here, the deduction permitted under the Code for casualty losses to personal property. These provisions mark, for our purposes, the extent of the relevant statutory material. They have, over the years, received detailed examination in the literature. ${ }^{5}$ Almost without exception these inquiries have taken as their outer limit the Code's current structure and have attempted only to interpret

*A.B., I964, Columbia University; B.A., 1966, Oxford University; LL.B., I968, Yale Law School; Associate Professor, University of Southern California Law Center.

I. Throughout this Article, the term "personal property" refers to property "not used in the trade or business" of the taxpayer and not "held for the production of income." See INT. REv. CODE of 1954. $\S \pm 67$ (a). The most common examples of such property are perhaps personal residences and automobiles used only for pleasure. In this Article, the term bears no relation to the distinction between real and personal property developed in English law.

2. "SEC. 262. PERSONAL, LIVING, AND FAMILY EXPENSES. Except as otherwise expressiy provided in this chapter, no deduction shall be allowed for personal, living, or family expenses." INT. REV. CODE of $1954, \S 263$.

3. "SEC. 212. EXPENSES FOR PRODUCTION OF INCOME. In the case of an individual, there shall be allowed as a deduction all the ordinary and necessary expenses paid or incurred during the taxable year- (x) for the production or collection of income; (2) for the management, conservation, or maintenance of property held for the production of income; or (3) in connection with the determination, collection, or refund of any tax." INT. REv. CODE of I954, \$2I2.

4. "SEC. I65. LOSSES. (a) General Rule. - There shall be allowed as a deduction any loss sustained during the taxable year and not compensated for by insurance or otherwise. . . . (c) Limitation on Losses of Individuals. - In the case of an individual, the deduction under subsection (a) shall be limited to-

"....

“(3) losses of property not connected with a trade or business, if such losses arise from fire, storm, shipwreck, or other casualty, or from theft." INT. REv. CoDE of $1954, \$ 165$ (a), (c) (3).

5. See, e.g., de Kosmian and Magill, The Internal Revenue Code of 1954: Income, Deductions, Gains and Losses, 68 Harv. L. Rev. 201 (1954); Groh, Involuntary Conversions and Castalty Losses, 35 Taxes 589 (1957); Lee, Losses on Depreciable Property under Section 165 of the Internal Revenue Code of 1954, no How. L.J. I (1964); Note, Income Tax Deductions for Personal Casualty Losses, 24 GEO. WASH. L. Rev. I35 (1955); Note, Taxation: Income: Deductibility of Castalty Losses, I8 ORIA. L. Rev. 208 (I965); Comment, The Casualty Loss Deduction and Consumer Expectation: Section ${ }_{16}{ }_{5}(\mathrm{c})(3)$ of the Internal Revenue Code, 36 U. CHI. L. REv. 220 (1968). 
the difficult points of statutory language in light of the cases decided in accordance with the Code's terms. But the structure itself needs reexamination, because the results it yields are incorrect when measured against the economic benefits that personal property provides its owner. This Article will seek to demonstrate the proper relationship between the general economic definition of income and the appropriate substantive law in cases of the conversion or disposition of personal property.

In his work on Personal Income Taxation, the economist Henry Simons defined personal income as the "algebraic sum of $(x)$ the market value of rights exercised in consumption and (2) the change in the value of the store of property rights between the beginning and end of the period in question." Simons' definition of income does not, of course, stand alone in the legal and economic literature. Indeed, both lawyers and economists have extensively debated the scope and extent of the concept of income. The Supreme Court in Eisner v. Macomber ${ }^{7}$ made the most famous judicial foray into the question when it defined income as the gain derived from capital, from labor, or from both combined..$^{8}$ In the economic literature, definitions have taken different approaches. For example, some have sought to define income in a manner that excludes, even after realization, all gains from capital investments. ${ }^{9}$ Still others have sought to limit the concept of income to recurrent receipts like dividends and salaries. ${ }^{10}$

The need for some definition to shape the inquiry should be clear. Mr. Justice Pitney put the matter well in Eisner $v$. Macomber when he said that Congress could not in discharge of its legislative role define income in a manner that satisfied only its unfettered discretion. ${ }^{11}$ If the question of definition is avoided, and some alternative course adopted, then how can the results be tested? Surrey and Warren's remarks do contain much truth:

Essentially the concept of income is a flexible one, with the result in a particular case being determined by the interplay of common usage, accounting concepts, administrative goals, and finally judicial reaction .... to these forces. Each force

\section{H. Strons, Personal Income Taxation 50 (1938).}

7. 252 U.S. I 89,207 (1920).

8. This definition, which has become associated with Eisner v. Macomber, was applied in two earlier cases. See Doyle v. Mitchell Bros., 247 U.S. 179, I85 (1918); Stratton's Independence v. Howbert, 23I U.S. 399, 4 I5 (1913).

9. Sce R. GCODE, THE INDIVIdual INCONE TAX I87-9I (I964); L. Seltzer, The NATURE AND Tas Treatament of Capital Gains and Losses 8-iI (I95I).

Io. See E. Allen \& O. Brownlee, Economics of Public Finance 248-49 (I947); Plehn, The Concupt of Income, as Recurrent, Constumable Receipts, I4 ANIER. EcoN. REv. I (r924). Simons takes PIchn to task for his dcfinition. H. Simons, supra note 6, at 74-75. See also U.S. v. Supplee-Biddle Hardware Co., 265 U.S. 189 , I95 (1924).

Ix. "[I]t [is] essential to distinguish between what is and what is not 'income' as the term is there used; and to apply the distinction, as cases arise, according to truth and substance, without regard to form. Congress cannot by any definition it may adopt conclude the matter, since it cannot by legislation alter the Constitution, from which alone it derives its power to legislate, and within whose limitations alone that powcr can be lawfully exercised." 252 U.S. I89, 206 (1920). 
and judicial reaction in turn reflects . . . an underlying judgment as to what types of receipts should be subject to a tax imposed on 'income.'.12

Yet the use of an explicit definition enables the inquiry to be structured and thus permits the effect of each material element to be isolated and accorded its proper weight. To state only that a concept is "flexible" does not offer a guide in concrete cases, nor does it determine the proper "interplay" among contending forces. Here is not the place to argue again in general form the merits of Simons' definition. Simons himself has made the strongest possible case in economic terms for its adoption. This Article will try only to demonstrate its worth by applying it to particular cases and comparing its results with those reached under the tax Code. But even in advance of the detailed analysis, two reasons support the belief that Simons' definition is superior to its alternatives as a tool for examining the problems of income taxation. First, it is the most comprehensive definition of income that has been advanced. ${ }^{13}$ Hence, more than any of the suggested alternatives, it reflects the Supreme Court's view, as expressed in Glenshaw Glass, $^{14}$ that the term income, as it appears in a taxing statute, ought to be given the broadest possible construction. Second, and more to the point here, the first branch of the definition makes explicit the effect of consumption as an economic matter upon the determination of income. True, the definition, even if sound as an economic matter, does not provide the solution to all problems of federal income taxation. If, on the other hand, the treatment accorded a transaction under current law does not yield the results required by a consistent application of the definition, then at the very least some explanation for the discrepancy is in order, for sound economic definitions are entitled to presumptive force in the law.

At least two sorts of explanations have been frequently given to account for discrepancies between particular legal results and the general economic theory. First, either as a matter of convenience or of constitutional mandate, the courts have added to the economic definition of income the require-

12. Surrey \& Warren, The Income Tax Project of the American Lawv Institute: Gross Income, Deductions, Accounting, Gains and Losses, Cancellation of Indebtedness, 66 HARv. L. REv. 761, 77I (1953).

13. Indeed, in many cases it may well be too broad. For example, Simons' definition requires all gifts to be taken into income by the donee, because gifts represent an increase in the value of his store of property rights, but the Code specifically excludes gifts from income. INT. REv. CoDE of I954, $\S 102(a)$. Gifts are not taxed because they do not, when both donor and donee are taken into account, represent any increase in wealth. In order to tax the donee, a deduction for the donor is in order-a result that does not square well with a progressive tax rate. Simons himself attempts to defend the broad scope of his definition, but he appears to depart from it when he insists that the donor be denied a deduction for a gift, even as he requires the donee to take the gift into income. H. Simons, supra note 6 , at $51-57,125-47$.

I4. Commissioner v. Glenshaw Glass Co., 348 U.S. 426 (1955). Section 22 (a) of the r939 Code, after enumerating specific classes of receipts included in gross income, concludes with the phrase, "gains or profits and income derived from any source whatever." Of this phrase, the Supreme Court noted: "This Court has frequently stated that this language was used by Congress to exert in this field "the full measure of its taxing power." "Id. at 429. 
ment of realization..$^{15}$ At its most basic level, this requirement states that a simple increase in an asset's value is not, without more, the proper subject for the imposition of a tax. The asset must undergo some kind of disposition or conversion, voluntary or involuntary, before the accrued gain can be taxed. The realization requirement ${ }^{16}$ has received extensive examination since it was laid down in Eisner v. Macomber, but it will be treated for the purposes of argument as sound in the following analysis.

Second, Simons' definition can be criticized because it requires all forms of imputed wealth to be taken into account (under the first limb of the definition relating to rights exercised in consumption) in the calculation of income. As an economic matter taxation of imputed income has received vigorous and sound defense, but as an administrative matter the prospect has been greeted with horror because of difficulties in identifying and evaluating each item of imputed wealth. Hence today, as a universal rule, the rigor of the economic definition of income gives way to the administrative difficulties of its application. ${ }^{17}$

The exemption of imputed income from taxation is unimportant in evaluating most business transactions, for profit and not consumption is the goal in business. In transactions with personal property, however, consumption must play a large, if not leading, role in the determination of income. Yet the Internal Revenue Code, in its preoccupation with business transactions, makes no attempt to take into account the first limb of Simons' definition in its treatment of taxable income.

\section{The Need for Basis Adjustment in Personal Property}

The administrative problems mentioned above seem to preclude the taxation of imputed wealth where it represents, in an economic sense, cur-

15. Whether realization is still a requirement in a constitutional sense is not clear. Opinions since Eisner $v$. Macomber have indicated dissatisfaction with the result, but most of the attacks on that case have concerned the appropriateness of its famous definition of income. Even in the cases that have retreated from Eisner v. Macomber, the term realization has played a part in the decision. In United States v. Kirby Lumber Co., 284 U.S. I (x931), Mr. Justice Holmes noted: "The defendant in error has realized within the year an accession to income, if we take words in their plain popular meaning, as they should be taken here." Id. at 3 (I93I). And in Commissioner v. Glenshaw Glass Co., 348 U.S. 426 (1955), the Court stated: "Here we have instances of undeniable accessions to wealth, clearly realized and over which the taxpayers have complete dominion." Id. at 431 . Both of these cases cannot be reconciled with the narrow definition of income in Eisner v. Macomber. In Kirby Lumber, the Court held that the taxpayer realized income when it redeemed bonds, previously issued in exchange for cash, for an amount less than the proceeds received upon sale. In Glenshaw Glass, the Court held that punitive damages received in an antitrust action were taxable income. In neither case is the gain derived, in any clear sense, from the use of capital or labor, or both combined. Income, however, is present in both cases under the terms of Simons' definition.

16. The sale of stock furnishes perhaps the most frequent instance of the realization of gain or loss. The taxation of unrealized appreciation of the stock of publicly held corporations, on the grounds that it represents income in the economic sense, has been seriously proposed. See Slawson, Taxing as Ordinary Income the Appreciation of Publicly Held Stock, 76 YALE L.J. 623 (1967).

17. For a discussion of the administrative problems of imputed income see H. Snons, supra note 6, at I Io-24; W. Vickery, Agenda for Progressive TAxation i 8-35 (I947). 
rent income, but those problems are not decisive on basis questions, even in cases of imputed wealth. When a taxpayer devotes property to personal use, he recovers his initial cost not in terms of cash, as does the businessman, but in terms of the pleasures afforded through consumption. The general rule of taxation requires appropriate adjustments in basis to reflect cost recovery. Basis adjustments can be made for personal property without administrative difficulty since they need be a function only of the expected life and the initial cost of the asset in question. Once basis adjustments for personal property are made, they will be reflected in the gain or loss recognized subsequently upon disposition or conversion of the property. Here, as a practical matter, some of the benefits of imputed wealth can be taken into account as income, but the Code entirely ignores this possibility.

Examining the results produced by the Code in specific cases illustrates its shortcomings. Consider first the treatment of depreciable property devoted to the personal use of the taxpayer. For the moment, assume that changes in value over the property's life reflect only its depreciation and not fluctuations in market demand. Under the current law, a taxpayer is not entitled to a writeoff against gross income for the depreciation of his personal property during the tax year. ${ }^{18}$ Since no writeoff is permitted against gross income, the Code then allows a taxpayer to retain, without downward adjustment, his cost basis in the property for use in the computation of gain or loss. The Code treatment is based on the assumption that a reduction in basis is required if and only if a writeoff against gross income is permitted. ${ }^{19}$

This absolute interdependence between writeoffs and basis adjustments can neither be justified under the terms of Simons' definition nor be explained by the realization requirement. Personal and business property decline in value on account of wear and tear, and in both cases the taxpayer should be required to reduce basis to account for the recovery of capital through use. In the business case, however, a deduction must be allowed against income under Simons' definition, because the exhaustion of capital represents a loss and not consumption, even though that loss is ultimately offset by the income derived from the taxpayer's activities. Personal property, on the contrary, produces an increment to income in the form of consumption that itself offsets the loss from depreciation. Consequently,

I8. "SEC. I67. DEPRECIATION. (a) General Rule.-There shall be allowed as a depreciation deduction a reasonable allowance for the exhaustion, wear and tear (including a reasonable allowance for obsolescence) - (I) of property used in the trade or business, or (2) of property held for the production of income." INT. REV. CODE of 1954 , \$ I 67 (a).

I9. "SEC. 1016. ADJUSTMENTS TO BASIS. (a) General Rule.-Proper adjustment in respect of the property shall in all cases be made-(2) in respect of any period since February 28, 1913, for exhaustion, wear and tear, obsolescence, amortization, and depletion, to the extent of the amount(A) allowed as deductions in computing income under this subtitle or prior income tax laws ...." INT. REV. CODE of I954, § IOI6(a)(2)(A). 
under Simons' definition the taxpayer should not be entitled to a writeoff against gross income for depreciation because his loss in property value has been offset by an equal benefit in consumption. Notwithstanding the Code's current provisions, a reduction in basis should be required regardless of the kind of property in question, whereas a writeoff is proper only for depreciation of business property.

An example illustrates the proper method of taxation for depreciable personal property. Consider a case of depreciable property, dedicated to personal use, with a cost of $\$ 100$, with an expected life of 20 years, and with a value that does not lluctuate at any point in its life because of changes in market conditions. If the taxpayer makes uniform use of his property over its expected life, then he consumes in each taxable year $\$ 5$ worth of that property. After 20 years, he will recover, in the form of consumption, an amount precisely equal to his initial investment in the property, or the full $\$ 100 .{ }^{20}$ Under current law his basis remains at \$roo throughout, but no tax results turn on that fact, assuming no sale or disposition occurs after the property becomes worthless.

The proper computation of basis, however, is crucial whenever the property is disposed of before it has been exhausted. In the previous example, assume that the owner decides to sell the asset after he has used it for five years. Under the current law he need not reduce his basis because the asset was not used in his trade or business. Selling the property for its fair market value of $\$ 75$ will produce a loss of $\$ 25$ since the basis is still $\$ 100$, but the loss is not recognized under present law because it is not a business loss. ${ }^{21}$ The net effect of the Code's rules is that the taxpayer recognizes no gain or loss at any time from the acquisition to the disposition of the property. In this particular case the Code's result conforms to the treatment required by Simons' definition. The reduction in the taxpayer's store of wealth is $\$$ roo, representing the initial cost of the property in question. The benefits realized by the taxpayer are two: $\$ 25$ in consumption over the previous 5 years and $\$ 75$ in proceeds received upon its disposition. Since the benefits received exactly offset the costs incurred, gain or loss need not be recognized at the time of sale.

The Code achieves the proper result only because it makes two errors in principle that cancel themselves out in effect. First, the Code refuses to take consumption into account, even as an adjustment to basis. Second, it refuses, except in some limited cases, to take the losses into account in the computation of income because they are personal. ${ }^{22}$ The Code's result

20. In this and in all following examples, income that should be imputed currently is ignored. Thus, on the assumptions made in the text, the taxpayer should enjoy well over \$roo in benefits from the use of his property over the 20-year period.

21. See Treas. Reg. $\S$ I.262-I (b) (4) (1958).

22. INT. REv. CODE of 1954 , \$165(c); Treas. Reg. § 1.262-r(b) (4) (1958). 
will be correct only when the property's value is unaffected by changes in market demand over the period it is held. Once that assumption is relaxed, the tax results are certain to be wrong in a way that does not systematically benefit either the government or the taxpayer.

To make this point clear, consider several variants of the example discussed above. First, assume that the property's market value doubles at the end of the fifth year, from $\$ 75$ to $\$ 150$. On this assumption the taxpayer has income, in a strictly economic sense, attributable to the increase in the value of the store of his property rights, even though he does not realize the income under the rule in Eisner v. Macomber. Suppose the taxpayer then retains the property for his own use for the remaining fifteen years of its expected life. Over the period he will consume the $\$ 75$ gain, but none of it will be taxed absent realization. Using the Simons definition, however, the result is different: The income derived through consumption is equal to $\$$ I75, of which $\$ 25$ was enjoyed in the five years before the change in market conditions, and $\$ 150$ in the remaining fifteen years. Against this figure of $\$ 175$ must be offset as a loss, under the second limb of the definition, the $\$ 100$ used to purchase the property now worthless at the end of the period. The difference between the two figures, $\$ 75$, represents the income that was enjoyed but not taxed to the owner. No sound theoretical reason supports not taxing this $\$ 75$ gain at some point. Only administrative problems of valuation, created in large part by the absence of realization, allow this gain to escape taxation.

These administrative problems do not require abandonment of the economic theory where the $\$ 75$ appreciation in the fifth year is captured not through use but through sale. Assume that at the end of the sixth year of ownership the taxpayer sells the property in an arm's length transaction. If subsequent changes in value only reflect the \$Io of further depreciation (\$ro because the asset has, after the fifth year, a value of \$I5O and an ex-

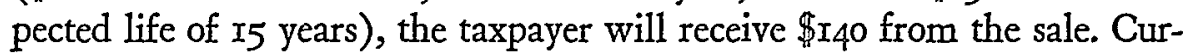
rent law demands recognition of only $\$ 40$ in gain from the sale, because the undepreciated cost of the property, $\$$ Ioo, is set off against the proceeds, \$I40. This result differs from that reached under Simons' definition: \$35 of the initial investment has been recovered in the form of rights enjoyed in consumption, of which $\$ 25$ represents the value of recovery for the first 5 years, and \$ro the value of the recovery in the sixth year. In addition, the taxpayer received at the end of the sixth year $\$ I 40$ in cash, so the total amount of his benefit from the property equals $\$ I 75$. Since only $\$$ I00 was invested initially, $\$ 75$ ought to be taxed at some point, but under current law the gain upon sale, calculated by reference to cost (\$IOo) basis, is only $\$ 40$. The $\$ 35(\$ 75-\$ 40)$ that escapes taxation is the income derived not in cash but in use. If in earlier years basis had been reduced to reflect the 
recovery of cost through use, then $\$ 30$ of the $\$ 35$ of untaxed gain would be caught at the time of disposition. The taxpayer's basis should be not $\$$ Ioo but only $\$ 7$, allowing $\$ 5$ of cost recovery for each of 6 years of use. Accordingly, the gain should be $\$ 70$, equal to the amount realized (\$140) less the adjusted basis $(\$ 70)$. The difference of $\$ 5$ between the economic and the taxable gain can be explained by looking to the realization requirement. The $\$ 5$ of appreciation consumed during the sixth year was never realized by conversion or disposition and hence escapes tax. The escape from tax of the remaining $\$ 30$ under current law can be attributed not to the realization requirement but only to the Code's improper basis provisions.

These errors in principle do not always work to the taxpayer's advantage. Assume that the value of this same property has, on account of market forces, fallen from $\$$ Ioo to $\$ 80$ shortly after purchase. Assume further that the property had been held and used for a period of five years and then sold for $\$ 60$. In this situation, the taxpayer sustains, in terms of Simons' definition, a loss of $\$ 20$ that under present law will go unrecognized for all time. ${ }^{23}$ Of the $\$ 100$ cost of the property, $\$ 20$ was recovered through consumption- $\$ 4$ per annum over a period of five years-and another $\$ 60$ was recovered at the time of sale. The initial reduction of market value in the first year reflects a loss in value not offset by benefits in consumption. Because of the realization requirement that loss is unrecognized when sustained; it should, however, be recognized after sale. The taxpayer should be required to reduce his basis to $\$ 75$ in order to reflect recovery of cost through consumption and then, upon sale, be allowed to recognize a $\$$ I $_{5}$ loss. He would, under this treatment, be able to recover $\$ 95$ of his initial investment- $\$ 60$ in sale proceeds; $\$ 20$ from consumption over the previous five years; and $\$ 15$ as allowable loss upon sale. Only the realization requirement prevents an exact cost recovery because, in each of the five years prior to the sale, the basis adjustments were made on the assumption that $\$ 5$ of cost was recovered through consumption. Since market value fell in the first year, however, the cost recovery was in fact only $\$ 4$, leaving a series of $\$$ I losses. Without realization of the loss in the year it occurred, neither income nor basis could be adjusted before the time of sale to take into account the total of $\$ 5$ in loss. Upon sale that loss remained unaccounted for, leaving cost recovery to that extent incomplete.

The current law provides, of course, that all losses on the sale of personal property shall not be recognized. The result cannot be reconciled with Simons' definition of income, which treats all losses in the same manner regardless of their origin. If the taxpayer were required to write down his basis to reflect consumption of personal property, loss upon sale would

23. See Treas. Reg. § 1.262-I (b) (4) (1958). 
occur less frequently because the taxpayer would be required to use his depreciated, not his original, basis in all computations of gain or loss. Where losses, properly calculated, do occur on sale, they should be recognized, since realization has taken place. A consistent theory of cost recovery is applicable to both personal and business property, but the Code makes provision for it only in the latter case.

\section{REPAIRS AND IMPROVEMENTS}

The conclusions thus far reached in the discussion of depreciable property dedicated to personal use can be extended further to the distinction the Code makes between repairs and improvements of personal property. Under current law a taxpayer is permitted to increase his basis on account of improvements and then to retain that increase in full until disposition, regardless of the amount of depreciation that subsequently occurs. His repairs, however, are regarded as personal living expenses, thus providing him with neither an immediate deduction nor a step-up in basis.

The current treatment of repairs and improvements is defective. In both cases the expenditures should entitle the taxpayer to increase his basis, on the condition that he reduce it each year to reflect his cost recovery through use. The Code's treatment of improvements, however, allows a taxpayer to treat benefits in excess of his initial investment as a return of capital. No new example is needed to illustrate the force of this point, because improvements are but the most common form of depreciable personal property whose tax treatment has already been considered. ${ }^{24}$

The difficulties in the current treatment of repairs, which presents slightly different problems, can be illustrated by a simple example. Assume that a taxpayer spends $\$ 1,000$ on his annual home repairs. Under current law that $\$ \mathrm{r}, 000$ is neither deductible nor added to basis. Under the proposed alternative the taxpayer would be allowed to increase his basis in his home by $\$ x, 000$ upon completing the repairs. One year later, if he still owns the house, he will be required to reduce his basis by $\$ 1,000$ to account for the benefits from the repairs recovered through personal use. At that point in time, whether the current law or the proposed modification is followed makes no difference, for neither current income nor basis will be affected by the choice. The results are no longer identical when, for example, the house is sold the day after the $\$$ r,ooo worth of repairs was completed. Under the current law the taxpayer would not be entitled to increase his basis by $\$ 1,000$ to reflect the repairs, whereas under the proposed alternative rules he would be entitled to a step-up in basis that would reduce his gain upon sale by an amount equivalent to the step-up. Unless the cost of repairs re-

24. See the examples in text accompanying notes $20-23$ supra. 
duces gain recognized upon sale, the taxpayer who sells immediately after making repairs will never be able to recover the costs in any form, either cash or consumption, since they provide benefit in use only to his purchaser. In other words, the current law permits the taxpayer who has made home repairs to recover his cost only through use, while the government can collect the full tax on improved property only if it is disposed of immediately upon completion.

These inequitable results can be overcome by explicit recognition of personal use (consumption) as an appropriate means of cost recovery. Little is gained by attempting to distinguish between repairs and improvements on theoretically inadequate grounds. The tests that look to the purpose, function, use, or effect of the expenditure generate only confusion and litigation, ${ }^{25}$ because in principle repairs and improvements are indistinguishable. Both are a function of the amount of the expenditure and the period over which the benefits derived therefrom can be expected to last. In a business context, the errors in classification lead only to mistakes in the timing of the tax benefits, for capitalization only postpones a cost recovery otherwise immediately taken as a deduction. The integrity of the general principle of cost recovery remains, however, unimpaired. In a nonbusiness context, the errors in classification produce dramatic consequences-consequences that go to the question of cost recovery itself. If the expenditure is classified as a repair, an adequate allowance for cost recovery is made only if the property is held for the full life of the repair; if the expenditure is classified as an improvement, the taxpayer who delays disposition of the improved property will be able to enjoy the use of the improvement without imputation of consumption income, and, when he sells the property, he can benefit from a step-up in basis reflecting the full cost of the improvement.

\section{Casualty Losses}

The Code's refusal to unhinge basis adjustments from writeoffs against income creates problems in the treatment of casualty losses of personal property that are illustrated by the case of Helvering $v$. Owens. ${ }^{26}$ The tax-

25. See, e.g., Illinois Merchants Trust Co., 4 B.T.A. 103, 106 (1926): "To repair is to restore to a sound state or to mend, while a replacement connotes a substitution. A repair is an expenditure for the purpose of keeping the property in an ordinarily efficient operating condition. It does not add to the value of the property, nor does it appreciably prolong its life. It merely keeps the property in an operating condition over its probable useful life for the uses for which it was acquired. Expenditures for that purpose are distinguishable from those for replacements, alterations, improvements or additions which prolong the life of the property, increase its value, or make it adaptable to a different use. The one is a maintenance charge, while the others are additions to capital investment which should not be applied against current earnings." See also Treas. Reg. $\$ 1.162-4$ (I963). The difficulties here are clear. Who would make a repair if it did not increase the property's worth? Although the remarks in Merchants Trust and similar language in the Regulations were made in a business context, they apply with equal force, or inadequacy, to personal property.

26. 305 U.S. 468 (1939). 
payer there purchased an automobile for $\$ 1,825$ and put it to his personal use for a period of years until it had a market value of $\$ 225$. It was then damaged in a collision, and its market value was reduced to \$Igo. The taxpayer and the government agreed that the loss was deductible under the Code's casualty loss provisions. ${ }^{2 \pi}$ The only dispute concerned its proper measurement. The government claimed that the taxpayer was entitled to deduct only $\$ 35$ for the actual loss sustained in the accident. The taxpayer sought a deduction equal in amount to the difference between his basis, in this case his cost in the automobile, and its market value after the collision, or $\$ 1,635$. The statute's language seems clearly to call for the result sought by the taxpayer, but the Court had little desire to allow the deduction in excess of the actual loss and chose, with the help of some questionable statutory intrepretation, to adopt the government's position, limiting the deduction to $\$ 35^{28}$

A proper treatment for the basis of the automobile in the first instance would circumvent the difficulty posed by the taxpayer's contention in Owens. The taxpayer should have been required to reduce his basis to reflect his cost recovery through consumption over the years the automobile was devoted to personal use. Then, at the time of casualty, he could continue his cost recovery by taking his loss as measured against his adjusted basis. The market value of the automobile before casualty would be immaterial in this case, since the taxpayer's loss, if any, would be measured in all cases by the difference between the adjusted basis before the casualty and the market value thereafter. An accident damaging a depreciated automobile would not generate a huge loss because initial cost would play no role in measuring the casualty.

Once proper basis adjustments were made, the Regulations' two-part rule to measure casualty losses-designed to dispose of the taxpayer's contention in Owens-would no longer be necessary. The Owens rule deter-

27. INT. REv. CODE of $1934, \S 165$ (c) (3), quoted in note 3 supra.

28. The Supreme Court argued from $\$ \S 23 \&$ \& 13 of the Revenue Act of 1934 . These provisions call for the same results as $\$ \$ 167$ (a) \& 1016 (a) of the I954 Code. The text of $\$$ Ir3 (b), which differs from the parallel language of $\$ 1016$ of the Code, guoted in note I9 supra, provides: "Adjusted basis. - The adjusted basis for determining the gain or loss from the sale or other disposition of property, whenever acquired, shall be the basis determined under subsection (a), adjusted as hereinafter provided.

"(I) General Rule-Proper adjustment in respect of the property shall in all cases be made-

“(B) in respect of any period since February 28,1913 , for exhaustion, wear and tear, obsolescence, amortization, and depletion, to the extent allowed (but not less than the amount allowable) under this Act or prior income tax laws." Revenue Act of I934, 48 Stat. $680 \mathrm{ch} .277, \S$ II3 (b). The words "allowed" and "allowable" mean allowed and allowable as deductions for depreciation under $\S 23$ of the 1934 Act, and the words "as deductions" do appear in \$ ror6 of the current law. The Court, however, held that the adjusted basis had to be used to measure the loss even though no deduction was allowed. Even on the Court's construction of the statute, the property's adjusted basis, not its market value before casualty, should be used to measure the loss. The result is correct in principle, but inconsistent with the statutory language, which, as the circuit court pointed out, fully supports the taxpayer's contention. Helvering v. Owens, 95 F.2d 318, 3I9 (2d Cir. 1938). 
mines the loss by subtracting the market value after the casualty from the lower of cost or market value before casualty. ${ }^{29}$ To the contrary, the principle of cost recovery indicates that all shifts in the value of property that are not a function of depreciation should be ignored, and the adjusted basis of the property before casualty should be the sole figure used in determining the deduction.

An example illustrates this contention. Consider again the case where a taxpayer purchases for $\$$ roo personal property with an expected life of 20 years. In its fifth year, the property, with an adjusted basis of $\$ 75$, doubles in market value to $\$ 150$. One year later, when it has a value of only $\$ 140$ on account of further depreciation, it is destroyed by an earthquake. On these facts, neither the market value of the property before casualty nor its initial cost furnish the proper basepoint for measuring the casualty loss. If cost is used, then the taxpayer will be able to take a deduction for $\$ 100$, even though he has already recovered, in the form of use before casualty, $\$ 35$ of his initial investment. He will thus be able to treat $\$$ r 35 worth of benefits as a recovery of capital, even though his initial investment is but \$Ioo. On the other hand, using market value to determine the deduction provides the taxpayer with an even greater windfall, for if the market value has increased he will be able to take a casualty deduction for accretions to value that were never taken into income. ${ }^{30}$ In effect the marketvalue standard increases total cost recovery to $\$ \mathrm{I}_{75}-\$ \mathrm{I}_{40} \mathrm{o}$ on account of the casualty loss and $\$ 35$ on account of prior use, while the initial investment

29. See Treas. Regs. § 1.165-7(b) (1960): "Amount deductible-(x) General rule. In the case of any casualty loss whether or not incurred in a trade or business or in any transaction entered into for profit, the amount of loss to be taken into account for the purposes of section 165 (a) shall be the lesser of either-

"(i) the amount which is equal to the fair market value of the property immediately before the casualty reduced by the fair market value of the property immediately after the casualty; or

"(ii) the amount of the adjusted basis prescribed in $\$$ I.IoI I-I for determining the loss from the sale or other disposition of the property involved. However, if property used in a trade or business or held for the production of income is totally destroyed by casualty, and if the fair market value of such property immediately before the casualty is less than the adjusted basis of such property, the amount of the adjusted basis of such property shall be treated as the amount of the loss for purposes of section I65(a)."

Using the full adjusted basis to measure the deduction in case of complete destruction of business property is in line with the arguments developed in the text. The Regulations appear to err, however, when they insist that in those cases in which the loss is only partial the fair market value before casualty be ured to measure the loss when it is less than the adjusted basis. In the case of partial losses the adjusted basis after the casualty deduction bas been allowed should in all cases be equal to the market value of the property after the casualty.

30. See Alsop v. Commissioner, 290 F.2d 726 (2d Cir. 196r). In Alsop, the court held that a cash basis taxpayer could not take a bad debt deduction for debts to her that were never paid, because she had never talen the obligations into income. The analogy to the example in text is clear, for the taxpayer never takes the appreciation of the destroyd property into income. Hence, he should not be allowed to take a deduction for the loss of an investment that, for tax purposes, he has never made. If the taxpayer were prepared to take that appreciation into income, he could claim that the full value of the property is the proper measure of the deduction. Because such an increase in income precisely offsets the increased deduction, the net effect is a deduction equal to the property's adjusted basis. Whenever a taxpayer is permitted a deduction for value never taken into income, he can write off the deduction against his taxable income, and income that should be taxed escapes taxation. 
remains but $\$$ Ioo. Hence, both of the alternate measures for the loss set out in the Regulations lead to economically improper results.

A coherent scheme of cost recovery is possible only if the extent of the deduction is determined with reference to the adjusted basis of the property before the casualty occurred. The taxpayer will be able to add his casualty loss of $\$ 70$ to the $\$ 35$ in benefits already derived through the use of the property. The total cost recovery is now $\$ 105$, a figure that differs from the economic ideal only because $\$ 5$ of consumed appreciation in the sixth year escapes taxation. The realization requirement thus accounts for the difference between the legal and the economic results.

The Regulations' two-part rule is also inadequate when the value of the depreciated property is less than its adjusted basis. Recall the case in which the taxpayer paid \$roo for a depreciable nonbusiness asset with an expected life of 20 years. Shortly after the purchase its value fell to $\$ 80$. The taxpayer held the asset for 5 years until its market value was $\$ 60$, but then suppose that instead of being sold, the asset is completely destroyed by an earthquake. Under the current law the taxpayer is entitled to take a deduction of only $\$ 60$, which represents the lower of cost or market at the time of the casualty, so of his investment of $\$$ roo he will be able to recover only $\$ 80$ in the form of personal use and tax deductions. In light of the arguments just developed, he should have been allowed to take a casualty deduction for $\$ 75$, the adjusted basis of the asset, so his total cost recovery would be $\$ 95$, $\$ 20$ through use and $\$ 75$ through deductible loss. Full recovery of \$IOO is impossible again only because of the realization requirement. In each of the five years that the asset was held, the taxpayer is treated as having recovered through consumption $\$ 5$ of benefits, when in fact but $\$ 4$ were benefits and $\$ \mathrm{I}$ was an unrealized loss. Since these past errors cannot be rectified at the time of casualty, the five years of $\$ \mathrm{r}$ losses must go unrecognized. This realization requirement should not, however, affect the character of deductible losses but should only determine the timing and feasibility of the recognition of losses. A sale is an appropriate occasion for the recognition of loss. So, of course, is a casualty.

In cases of casualty loss the casualty is not the measure of the loss, but only the occasion for recognizing losses that occur, in an economic sense, both prior to the casualty and because of it. Contrary to the Code, a casualty should not be a necessary condition to recognizing losses. Other sorts of events, not covered by the casualty provisions, should also be considered appropriate occasions for recognizing economic losses. The Code now requires the courts to draw, in terms more appropriate to the law of torts, the unsatisfactory distinction between forces that cause damage in a sudden and dramatic way and those that achieve the same effect in a quiet 
but persistent manner. Freezes, vermin, termites, earthquakes, insects, thefts, erosions, explosions, and vandalism must be classified as deductible or nondeductible losses, ${ }^{31}$ but in terms of Simons' definition any classification of losses is out of place since all of these events reduce the value of the taxpayer's store of rights.

The considerations invoked by the courts are only material to the allocation of a loss between taxpayers in accordance with principles of civil liability, but once a particular loss is fastened upon a given taxpayer, the appropriate tax treatment should be determined solely by reference to the economic definition of income, as it is modified by the realization requirement. All losses should be recognized upon realization, not only casualty losses.

\section{Treatiment of Insured, Uninsured, and Legally Imposed Losses}

The casualty loss provisions, then, are far too narrow because they select without justification one class of losses from all the others and give to it alone a preferred tax treatment. The inadequacy of those provisions is compounded where the loss in question is shifted by an insurance contract or by the successful prosecution or settlement of a tort claim.

\section{A. Insured and Uninsured Losses}

Consider first the impact of insurance upon the taxation of losses, and assume that the owner of property suffers a loss in a manner not covered under the Code's casualty provisions; for example, he loses his ring at an amusement park. If the loss is uninsured, it will not be taken into account on any tax return. The owner has a nondeductible personal loss, and the insurance company bears no expense for indemnification. In the alternative, assume that the loss is covered by insurance so the risk of loss is shifted, under contract, from the owner to the insurer. Since he is insured, the taxpayer will receive compensation for his loss. The loss of the ring will not be reflected in his tax return, since it is offset by the insurance received ${ }^{\mathbf{3 2}}$ For the insurance company the payment made to the owner under the terms of his policy will be deductible as a business expense under section I62. The loss of the ring, nondeductible to its owner, is by a contract of insurance transformed into a deductible loss for the company. No economic

3I. For complete classification of the hazards that have been adjudged to fall on one side of the line or the other see MfcDowell, Casualty Losses, I7 N.Y.U. INST. oN FED. TAx. 627 (r959); Rabin, Castualties and Disaster Losses are Deductible: The Do's and Don'ts, U. So. CAL. 1964 TAx INST. 463. 32. When the property's fair market value exceeds its adjusted basis, the taxpayer should recognize a gain, upon the receipt of the proceeds of insurance, equal to the difference between the amount realized and his adjusted basis. But since the realization of the gain is involuntary, there is a strong case to be made for postponement of its taxation. Code \$ 1033 allows a taxpayer whose property has been subject to involuntary conversion to escape taxation on any gain realized to the extent that the proceeds from the conversion are reinvested, usually within one year, in property of a like kind, on condition that the old basis is carried over to the new property. 
reason explains why shifting the loss should create the deduction, and the realization requirement, fulfilled in both cases, cannot account for the difference in result. It is hard to quarrel with the allowance of the deduction to the insurance company, because its payment represents a legitimate business expense. Parity between this case and the no-insurance case is restored only if the owner is allowed to claim for himself the deduction for the casualty loss. A contract of insurance should only determine who is entitled to take the deduction, not whether it exists.

\section{B. Legally Imposed Losses}

The same analysis applies with equal force where the loss in question is the subject of a tort action. $A$ owns a home situated on the base of a hill and has a neighbor, $B$, who lives on the hilltop. During the summer, rains work themselves down from the top of the hill causing damage to the foundation of $A$ 's home. First, assume that the loss is attributable to a casualty. If $A$, under the applicable substantive law, is unable to recover in damages in a tort action against $B$-the only possible defendant-then he will, absent any question of insurance, be able to deduct his loss. Thus far, the legal and the economic analyses coincide because the loss, now realized, is deductible. Now suppose that $A$ could recover in full for his loss from $B$. $A$ now cannot take any deduction because his loss is offset by the damage award; his situation is precisely that of the owner compensated by insurance. But $B$ will not be able to claim the loss for the casualty, even if he must bear it, because his loss is pursuant to judgment and thus does not fall within the enumerated classes of casualty losses. ${ }^{33}$

The successful prosecution of the tort claim for casualty losses thus creates a situation that is the reverse of the case of insured losses. The shift in the loss does not create but destroys a deduction otherwise allowable, even though the tort suit presupposes the existence of a loss whose incidence it shifts. Again, all difficulty is avoided if deductions are allowed on realization for all losses. Once payment made under legal compulsion is found not to be a form of consumption, as clearly seems the case, it should be treated as just another loss. Payment of the award is a clear form of realization, so the legal result need not diverge from the economic.

Now assume that the loss in question is not attributable to a casualty, within the Code's meaning, so $A$ cannot claim a deduction. If $B$ does not

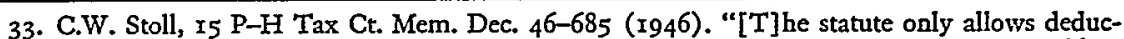
tions for losses of property belonging to the taxpayer and $\ldots$ we did not construe money paid to injured parties as being a loss of the taxpayer's property within the intendment of the statute." Id. at 46-687. "A payment by the taxpayer as compensation for injury to a person or his property is not deductible as a loss from casualty, since the statute authorizing such deduction contemplates that the damage from casualty shall be to the taxpayer's property rather than that of another." Annot., 20 A.L.R.2d 600,617 (I95I). The same rule applies where the damages paid are compensation for personal injuries, and not property damage. Mulholland v. Commissioner, I6 B.T.A. I33I (1929). 
make payment to $A$ pursuant to court order, $B$ will have no reason to claim a deduction either. If, alternatively, $A$ recovers from $B, B$ cannot claim a deduction because payment under legal compulsion is not a casualty loss. Shifting the loss from one party to another does not create or eliminate a tax deduction, but both results should not be assumed correct simply because they are consistent. Instead, both results are wrong because they presuppose, contrary to the economic definition, that for noncasualty losses no deductions should be allowed even after realization.

The law achieves the correct result in some cases by providing that a taxpayer who commits a tort in the course of his business or employment is entitled to deduct his damage payments, ${ }^{34}$ even though he would have to treat them as personal expenses if the tort were committed after business hours. The distinction is beside the point. The loss, once realized, should be recognized because it is a loss, not because it might have been "proximately" related to the taxpayer's business activities. Because of the erroneously narrow scope given to the personal deductions, torts are not uniformly treated as a single class of events, and only those tort losses that can be disguised as business expenses are deductible.

\section{Litigation Expenses}

The tax law now ties the deductibility of litigation expenses to the distinction between personal and business affairs contained in section 162 and section 212 of the Code. Yet here, as with damage awards, the crucial inquiry should only be: Do these payments represent consumption, or do they represent loss? The line between consumption and loss may be difficult to draw in some cases but the same is doubtless true of the line between business and personal expenses. Generally, litigation expenses are regarded as total losses by persons who are constrained to make them, even if judgment in the suit yields a recovery that must be taken into income on its own account. ${ }^{35}$ The complexity of discrete factual situations should not conceal the fact that currently the law, with its emphasis upon the distinction between business and personal expenses, draws what is in principle the wrong line. Once the error in principle is built into the law, the results in individual cases are made to turn on, among other things, whether the ex-

34. See Kornhauser v. United States, 276 U.S. 145,153 (1928): "[W] against a taxpayer is directly connected with, or ... proximately resulted from, his business, the expense incurred is a business expense ...."

35. This proposition seems tolerably clear in adversary proceedings, particularly for a defendant, who has no choice but to join a suit once he has been served. In certain situations, such as most child adoption cases, the cost of litigation probably does not represent a loss. Some of the hardest cases to decide seem to be those concerning divorce or separation. Perhaps the legal fees in divorce cases could be regarded as the purchase price for the freedom from an unwanted association, to be capitalized and written-off over the expected life of the party to the former marriage. In any case, fees paid in connection with divorce or separation are generally not deductible, unless associated with the collection and preservation of income. Treas. Regs. \$ $1.262-\mathrm{I}(\mathrm{b})(\mathrm{7})(\mathrm{I} 963)$. 
penditures arose from a business transaction or were made only to protect the title to property, be it business or personal $;^{38}$ whether they were in response to a frivolous, not a serious attack $;^{37}$ whether they. were incurred to preserve the taxpayer's liberty, ${ }^{38}$ or to protect his reputation; ${ }^{39}$ whether they were incurred in criminal, not civil proceedings. ${ }^{40}$ In none of these cases does the distinction between consumption and loss present serious difficulties of application, for none of these expenditures were for consumption, even though the taxpayer chose in all cases to make them. All were incurred in response to an attack upon the taxpayer. Resistance was the course of least peril because the alternatives carried with them the prospect of yet greater losses. The taxpayer who acts to minimize his losses should be entitled to a deduction for the losses he still must suffer.

Lykes v. United States ${ }^{41}$ and its legislative aftermath illustrates the soundness of this position. There, the taxpayer sought to deduct the legal expenses incurred when he successfully challenged a government assessment of a gift tax on the transfer to his children of shares in his closely held corporation. Under the Code, the Supreme Court only had to decide whether the deduction for these expenses was allowable under either section 162 or section 212 of the Code. The Court was satisfied that those expenses were not made in the pursuit of Lykes' trade or business, much less for the protection or maintenance of his property. Indeed, the regulations under the 1939 Code expressly denied the deduction sought by the taxpayer. ${ }^{42}$ Accordingly, it disallowed the deduction for which it could find no authorization.

36. See United States v. Gilmore, 372 U.S. 39 (I963); Hochschild v. Commissioner, I6I F.2d $8 \times 7$ (2d Cir. 1947). While the arguments in the text require writing off all expenses made in defense of property, these expenses are but one form of personal losses, and do not answer the question of when the taxpayer should be entitled to take his loss. When the defense of the lawsuit is successful, the expenses arguably should not generate an immediate deduction, because they provide benefits lasting as long as the taxpayer retains title to the property. Accordingly, capitalization of expenses would be the appropriate treatment, regardless of whether the property is business or personal. Alternatively, these expenses could be written-off over a period of years, on the model of $\$ 248$ of the Code, which allows for 5-year amortization of expenses incurred in forming a corporation. Currently, a taxpayer is allowed to deduct expenses in defense of title only when they arise out of his business activities. Hochschild v. Commissioner, supra. The arguments in the text do require that the same treatment be afforded all litigation expenses in defense of title, regardless of whether they are business or personal. 37. See Galewitz v. Commissioner, 4 II F.2d 1374 (2d Cir. 1969).

38. See Lewis v. Commissioner, 253 F.2d 821 (2d Cir. I958) (deduction denied for taxpayer's legal expenses in resisting commitment proceedings instituted by his wife because they did not arise out of any profit-seeking activity).

39. Draper v. Commissioner, 26 T.C. 201 (1956) (deduction allowed for litigation expenses incurred to protect professional reputation). But see Lloyd v. Commissioner, 55 F.2d 842 (7th Cir. 1932) (deduction disallowed for litigation expenses incurred to protect personal reputation).

40. See Commissioner v. Heininger, 320 U.S. 467 (1943) (criminal); Lewis v. Commissioner, 253 F.2d 821 (2d Cir. I958) (civil).

4I. 343 U.S. 118 (1952).

42. "Expenses paid or incurred by an individual in determining or contesting any liability asserted against him do not become deductible . . . by reason of the fact that property held by him for the production of income may be required to be used or sold for the purpose of satisfying such liability. Thus, expenses paid or incurred by an individual in the determination of gift tax liability, except to the extent that such expenses are allocable to interest on a refund of gift taxes, are not deductible, even 
It is hard to quarrel with the result reached by the Court given the framework of the Code. Nonetheless the decision strikes harshly, for Lykes' dispute with the government was not of his own making. True, he could have declined to contest the determination by the government, but only at the greater cost required by the payment of the tax. Indeed, Congress recognized the force of Lykes' claim when it amended the Code to permit the deduction of all expenses incurred in the determination, collection, or refund of any tax. ${ }^{43}$ In effect, the results achieved through statutory amendment are precisely those required by Simons' definition. The expenditures were imposed upon Lykes by the government, and to him they do not represent personal consumption. Since they did reduce his net worth, they must be regarded as an economic loss, deductible when realized upon payment. There is no need in principle for a special statutory provision to reach, after an unfortunate judicial decision, a result that follows without difficulty from the general principles developed in this Article.

\section{Conclusion}

The overall strategy of this Article should by now be clear. The point of departure was an economic definition of income, that proposed by Henry Simons. That definition requires the careful distinction between the consumption and loss of personal property, since the former is covered by the first limb of the definition and the latter by the second. The Internal Revenue Code does not incorporate that distinction within its framework, but treats consumption and loss as though they were but different instances of a single form of personal expenditure. When the Code makes an error in principle, errors in particular cases follow. Some of the odd results of the current law may be explained away, no doubt, because they are attributable to the twin problems of realization and imputed income, both of which raise practical concerns, even if they might be of theoretical indifference to economists. The distortions introduced into the law by each of these factors can be identified and isolated, however, leaving unaccounted for a number of results now required under the current law. Today, no adequate provision is made for cost recovery in the form of consumption or use. False distinctions are drawn in the taxation of both repairs and improvements of personal property. Most personal losses remain nondeductible, even after realization, because the Code insists without justification that

\footnotetext{
though property held by him for the production of income must be sold to satisfy an assesssment for such tax liability or even though, in the event of a claim for refund, the amount received will be held by him for the production of income." T.D. 5513, 26 C.F.R. $\$ 29.23(\mathrm{a})-15(\mathrm{k})$ (1946). This regulation is cited in Lykes v. Unized States, 343 U.S. at $126-27$.

43. "In the case of an individual, there shall be allowed as a deduction all the ordinary and necessary cxpenses paid or incurred during the taxable year- ... (3) in connection with the determination, collection, or refund of any tax." INT. REV. CODE of I954 §2I2.
} 
deductions for personal losses must be bottomed upon casualty. Finally, the status of litigation expenses is placed in hopeless confusion because now they must be treated as either business expenses or personal consumption, when in most cases they are neither, being but one form of loss. These defects in the Code can be corrected without administrative inconvenience, even if realization remains a prerequisite to recognition of gain or loss. Modifying the Code in light of the observations made in this Article would work toward making good on the promise to tax income, not something else. 